International Journal of Social Science and Economic Research

ISSN: 2455-8834

Volume: 05, Issue: 06 "June 2020"

\title{
REMITTANCES AND FINANCIAL INCLUSION IN AFRICA: A LONG RUN APPROACH
}

\author{
${ }^{1}$ NINGAYE Paul, ${ }^{2}$ ABBA YADOU Barnabé, ${ }^{3}$ BALLA MEKONGO Ghislain \\ 1,2,3 University of Dschang, Cameroon
}

DOI: 10.46609/IJSSER.2020.v05i06.012 URL: https://doi.org/10.46609/IJSSER.2020.v05i06.012

\begin{abstract}
This paper examines the link between migrant remittances and financial inclusion in Africa. Our sample consists of 29 African countries from 2004 to 2017. Using a system GMM and a Pooled Mean Group (PMG), we find that migrant remittances have a negative short-term but positive long-term effect on financial inclusion. In addition, migrant remittances increase access to financial services in the long run. However, remittances have a negative effect on the use of financial services. To benefit from migrant remittances, it would be useful to lower the transaction costs of migrant remittances and adopt financial instruments that can better channel these flows to productive sectors.
\end{abstract}

Keywords: Migrant remittances, financial inclusion, system GMM, Pooled Mean Group

\section{INTRODUCTION}

The growth and low volatility of migrant remittances in recent decades pose a real challenge for developing economies, which receive $74 \%$ of remittances and account for $27 \%$ of GDP (World Bank, 2014). Indeed, migrant remittances are one of the sources of external financing of economies and are broader than foreign direct investment and official development assistance.

For example, in 2019, migrant remittances to low- and middle-income countries reached $\$ 550$ billion, surpassing foreign direct investment and official development assistance in those countries (World Bank and Knomad, 2019). All six regions have seen an increase in migrant remittances due in particular to the growing economic situation in the United States and the rebound in remittances from some Gulf Cooperation Council countries. Official statistics on the amount of migrant remittances is underestimated due to the preponderance of informal remittance flows. Indeed, the flow of migrant remittances through non-financial institutions and informal channels accounts for $50 \%$ of this flow in Sub-Saharan Africa (Ratha et al., 2010). Moreover, this flow of migrant remittances is about 50 to $250 \%$ of official statistics according to Freund and Spatafora (2008). 


\section{International Journal of Social Science and Economic Research}

ISSN: $2455-8834$

Volume: 05, Issue: 06 "June 2020"

In addition, financial inclusion at the G20 summit in Seoul was placed high on the global development agenda. Financial inclusion is defined as access for individuals and enterprises previously excluded from the formal financial system to a range of useful and responsive financial products and services (transactions, payments, savings, credit and insurance) offered by formal financial intermediaries. For Sarma and Pais (2011), financial inclusion is a process that ensures the ease of access, availability and use of the formal financial system by all individuals in an economy. An inclusive financial system facilitates the efficient allocation of productive resources and thus has the potential to reduce the cost of capital (Sarma, 2008). In addition, it has been recognized that remittances from migrants play an important development role and financial inclusion is key (Global Migration Group, 2017).

Previous studies have examined the link between migrant remittances and financial inclusion in a superficial way by not considering all aspects of financial inclusion. A study that takes into account the different dimensions of financial inclusion should produce a more explicit understanding of this relationship. Moreover, apart from the work of Chuc et al. 2019) taking into account the different aspects of financial inclusion in Middle Income Countries (MICs), this study takes Africa into account.

Previous studies have considered the relationship between migrant remittances and financial inclusion by taking into account a financial inclusion indicator (Gemechu et al., 2014; Ambrosius et al., 2014; Inoue et al, 2016; Inoue and Hamori, 2016; Kwesi et al., 2020) and therefore provides partial information on financial inclusion (Sarma, 2008), based on a country (Anzoategui et al., 2014; Ajefu and Ogebe 2019) and taking into account a composite index.

In addition to the work of Chuc et al (2019) based on the case of middle-income countries (MICs), this study takes into account Africa composed of low-income countries (LICs) and lowand middle-income countries (LMICs). Moreover, in this study we take into account the dynamic and long-term impact of the relationship between migrant remittances and financial inclusion.

\section{LITERATURE REVIEW}

Reasons for the positive impact of migrant remittances on financial inclusion include the increasing amount that leads to a demand for a bank account (Ambrosius and Cuecuecha, 2016), reducing the risk of information asymmetry (Roa, 2015) which increases the creditworthiness of remittance recipients with lenders (Orozco and Fedewa, 2006; Chuc et al, 2019) and finally the promotion of financial literacy that eventually leads to financial inclusion (Yoshino et al., 2017).

\subsection{Theoretical review}

Theoretically, this study is based on the theories of asymmetry of information and pure altruism. 


\section{International Journal of Social Science and Economic Research}

ISSN: $2455-8834$

Volume: 05, Issue: 06 "June 2020"

The theory of information asymmetry has its roots in the work of George Akerlof on Lemons markets in 1970. This theory refers to the effect of moral hazard between market participants, where one of the market participants holds information not known by the parties and which leads to market inefficiency. Many arguments argue that a regular flow of migrant remittances makes it easier for financial institutions to hold information on the income of the recipients of these flows, thereby establishing their creditworthiness (Anzoategui et al., 2014; Ambrosius and Cuecuecha, 2016). In addition, remittances can be considered as collateral for obtaining credit, which aims to reduce problems of information asymmetry (Misati and Kamau, 2018; Toxopeus and Lensink, 2008). Such information could make financial institutions willing and able to provide credit and other financial products to remittance recipients (Brown et al., 2013). In addition, increased remittances may increase demand for bank deposit accounts as households need services to safeguard their temporary surplus income (Aggarwal et al., 2011; Anzoategui et al., 2014; Ambrosius and Cuecuecha, 2016).

The theory of pure altruism comes from the work of Lucas and Stark on the motivations for sending remittances to Botswana. In their study they divided the theories of remittances into three groups, namely pure altruism, pure self-interest and temperate altruism. According to the pure altruism theory, the migrant's satisfaction depends on the satisfaction of his or her family in the country of origin (Lucas and Stark, 1985). Thus, migrant remittances act as insurance for recipient households to cope with shocks by diversifying sources of income (Stark, 1991).

In pure self-interest, migrant remittances play a role in acquiring assets for the migrant such as land, houses, and investment in a project. According to Lucas and Stack (1985), pure altruism or pure self-interest cannot explain the growth of this flow and its variability. They propose a theory of tempered altruism whereby remittances are seen as part of an agreement between the migrant and the recipients in his or her country of origin. Thus, unlike remittances through the informal channel, remittances through bank accounts can encourage savings and investment (World Bank, 2005). Estimates show that $10 \%$ of remittance recipients save, invest and use them for entrepreneurial activity (Orozco and Fedewa, 2006).

\subsection{Empirical Review}

The impact of remittances on financial inclusion has been little developed, but studies have focused more on access to financial services, often taking into account a dimension of financial inclusion, such as the possession of an account or the availability of financial institutions by increasing the branches of commercial banks (Inou and Hamori, 2016) and their impact on credit (Brown et al., 2013; Ambrosius and Cuecuecha, 2016). Empirical studies on the impact of remittances on financial inclusion can be divided into two main parts. One part focuses on a 


\section{International Journal of Social Science and Economic Research}

ISSN: $2455-8834$

Volume: 05, Issue: 06 "June 2020"

simple approach based on a financial inclusion indicator and the other part focuses on a multidimensional approach.

Migrant remittances increase access to financial services (bank account ownership, increase in banking branches). The work of Anzoategui et al (2014) examining the impact of remittances on access to financial services in El Salvador shows that receiving migrant remittances increases the probability of having an account by $11 \%$. In addition, Ambrosius (2016) using data from Mexico finds that the impact of remittances increases the holding of savings accounts. However, remittances play a catalytic role for access to formal financial services if recipients are aware of the importance of formal finance (Inoue and Hamori, 2016).

Nevertheless, some work shows that remittances do not increase borrowing (Ambrosius, 2016; Anzoategui et al., 2014; Durga, 2019). Using household survey data in Mexico, Ambrosius and Cuecuecha (2016) study the effect of remittances on the use of formal and informal financial services. Their results show that remittances have a positive and significant impact on informal borrowing. However, studies by Aggarwal et al (2011), show that remittances from migrants increase the aggregate level of deposit and credit with financial institutions. Moreover, Gupta et al (2009), Demirguc-kunt et al (2011) confirm this.

Previous studies do not consider financial inclusion on a multi-dimensional level and some work is limited to a single period, such as the work of Durga (2019). These indicators of financial inclusion used individually provide partial information on financial inclusion and can lead to misinterpretation of the scope of financial inclusion (Sarma, 2008). Recent studies by Chuc et al (2019) attempt to close this gap, although they ignore the geographical dimension of financial inclusion. Indeed, studies by Chuc et al. (2019) show that remittance flows and financial inclusion are positively related to economic development. Moreover, using a generalized moment model and a Structural Equation Model (SEM), they show that remittance flows can boost financial inclusion. They construct a financial inclusion index following the approach of Wang and Guan (2017) which takes into account two dimensions of financial inclusion. Financial inclusion in their work takes into account the access and use aspect of formal financial institutions. They disregard the geographical dimension of financial inclusion, which is captured by the proximity of financial services, which itself according to Global Findex (2017) is a reason for financial exclusion.

\section{METHODOLOGY}

Our sample covers 29 African countries from 2004 to 2017 due to data availability. Variables are drawn from several data sources such as the World Development Indicator (WDI), Financial Access Survey (FAS), Global Financial Development Database (GFDD) and International Country Risk Guide (ICRG). 


\section{International Journal of Social Science and Economic Research}

ISSN: $2455-8834$

Volume: 05, Issue: 06 "June 2020"

\subsection{Measuring Financial Inclusion}

Several works have been undertaken to construct the financial inclusion index, such as the work of Sarma (2008). Sarma (2008) considers three dimensions of financial inclusion: banking penetration, availability of banking services, and use of banking services. The first and second dimensions are similar. Thus, in this study we consider two dimensions, namely access to and use of financial services. The use of banking services is motivated by two reasons, one of which refers to the notion of under-banked developed by Kempson et al (2004) and the second to the fact that the possession of a bank account is not sufficient for financial inclusion. In the dimension of access to financial services, we take into account demographic (Sarma, 2008) and geographical (Mialou et al., 2017) indicators. The indicators of the availability of banking services in terms of demographics come from the FAS database and include the number of bank machines per 100,000 adults and the number of ATMs per 100,000 adults. Indicators of financial services availability in terms of geography are the number of bank machines and the number of ATMs per $1,000 \mathrm{~km} 2$.

Like Sarma (2015), the financial services utilization dimension considers the volume of credit and deposits as a function of GDP. In this study we take into account for the use dimension financial sector deposits as a percentage of GDP from the Global Financial Development Database (GFDD), domestic credit as a percentage of GDP from the World Development Indicator (WDI) and mobile banking. The increase in the use of mobile banking in Sub-Saharan Africa. For mobile banking we use the mobile service subscription per 100 people from WDI. This indicator has been used by several studies on financial inclusion (Andrianaivo and Kpodar, 2012; Lenk and Barik, 2018).

For the construction of the financial inclusion variable (FII) we use the Principal Component Analysis (PCA) approach.

\subsection{Control variables}

Population growth (POPGROWTH) and population density (POPDENSITY) measures the demographic effect and population concentration on banking penetration. Some authors such as Beck et al (2005) find a correlation between banking availability and the size of the economy and especially population density. We take into account government investment (goveexp) measured by government spending as a proportion of GDP and inflation (inflation) measured as an annual percentage of the consumer price index to account for economic uncertainty. We consider the Human Development Index (HDI) because there is a positive correlation between human development and financial inclusion (Arindam, 2015). We measure the quality of institutions by taking the average of seven variables from the ICRG database, which include: corruption, law and order, government stability, democratic accountability, quality of bureaucracy, socio- 


\section{International Journal of Social Science and Economic Research}

ISSN: $2455-8834$

Volume: 05, Issue: 06 "June 2020"

economic conditions, and internal conflict. Internet access and subscription to mobile services have a positive impact on financial inclusion (Olaniyi, 2018). Thus, we measure internet access (internet) by individual internet use as a percentage of the population. Our variable of interest migrant remittances (remit) is measured as a percentage of GDP. FII, FIIusage and FIIaccess represent the financial inclusion index, the financial services usage index and the financial services access index respectively.

\subsection{Preliminary tests}

Table 1 shows the descriptive statistics of the variables and Table 2 the correlation matrix of the variables. It shows that remittances from migrants contribute on average 2.853919 of the percentage of GDP in our sample. Moreover, the correlation matrix shows us that there is a low correlation between the variables used.

Table 1: Descriptive statistics

\begin{tabular}{|l|l|l|l|l|l|}
\hline Variables & Observations & Mean & Std error & Min & Max \\
\hline remit & 406 & 2.853919 & 3.109463 & .0001832 & 13.61145 \\
\hline POPDENSITY & 406 & 58.62275 & 50.42111 & 2.440486 & 213.759 \\
\hline POPGROWTH & 406 & 2.534945 & .7258959 & .780902 & 4.51511 \\
\hline FII & 406 & .2069662 & .1575069 & $1.00 \mathrm{e}-09$ & 1 \\
\hline internet & 406 & 12.66746 & 14.03159 & .1899337 & 61.76221 \\
\hline ICRGmean & 406 & 4.228727 & .722095 & 2.5 & 5.857143 \\
\hline FIIusage & 406 & .275301 & .178766 & $1.11 \mathrm{e}-08$ & 1 \\
\hline FIIaccess & 406 & .2508143 & .1887087 & $2.47 \mathrm{e}-09$ & 1 \\
\hline goveexp & 406 & 14.03169 & 4.627847 & 2.047121 & 26.24226 \\
\hline inflation & 406 & 6.797134 & 6.77604 & -23.08492 & 43.54211 \\
\hline HDI & 406 & .522532 & .1087294 & .274 & .754 \\
\hline
\end{tabular}

Source: Authors 
International Journal of Social Science and Economic Research

ISSN: 2455-8834

Volume: 05, Issue: 06 "June 2020"

Table 2: Pearson Correlation Matrix

\begin{tabular}{|l|l|l|l|l|l|l|l|}
\hline & FII & remit & goveexp & inflation & HDI & popdensity & popgrowth \\
\hline FII & 1.0000 & & & & & & \\
\hline remit & 0.0733 & 1.0000 & & & & & \\
\hline goveexp & -0.0164 & -0.0727 & 1.0000 & & & & \\
\hline inflation & -0.0127 & -0.2066 & -0.2900 & 1.0000 & & & \\
\hline HDI & 0.0191 & -0.0907 & 0.2946 & -0.0337 & 1.0000 & & \\
\hline POPDENSITY & 0.1876 & 0.3361 & -0.3660 & 0.1968 & -0.1439 & 1.0000 & \\
\hline POPGROWTH & 0.0496 & -0.1681 & -0.3141 & 0.1476 & -0.6274 & 0.0649 & 1.0000 \\
\hline ICRGmean & 0.0602 & -0.1751 & 0.4244 & -0.0554 & 0.4445 & -0.1806 & -0.4049 \\
\hline FIIusage & 0.3696 & -0.0506 & -0.0044 & -0.0257 & -0.0292 & -0.0135 & 0.0038 \\
\hline FIIaccess & 0.4974 & 0.0956 & 0.0487 & -0.0510 & 0.0391 & 0.0034 & -0.0577 \\
\hline internet & 0.0316 & 0.1346 & 0.2663 & -0.0970 & 0.6612 & 0.0615 & -0.4809 \\
\hline & ICRGmean & FIIusage & FIIaccess & internet & mobile & & \\
\hline ICRGmean & 1.0000 & & & & & & \\
\hline FIIusage & 0.0616 & 1.0000 & & & & & \\
\hline FIIaccess & 0.0591 & 0.2569 & 1.0000 & & & & \\
\hline internet & 0.1371 & 0.0037 & 0.0647 & 1.0000 & & & \\
\hline SOurce: Author & & & & & & \\
\hline
\end{tabular}

Source: Author's 
Figure 1: Scatter Plot (remittances and financial inclusion index: FII, access and usage)
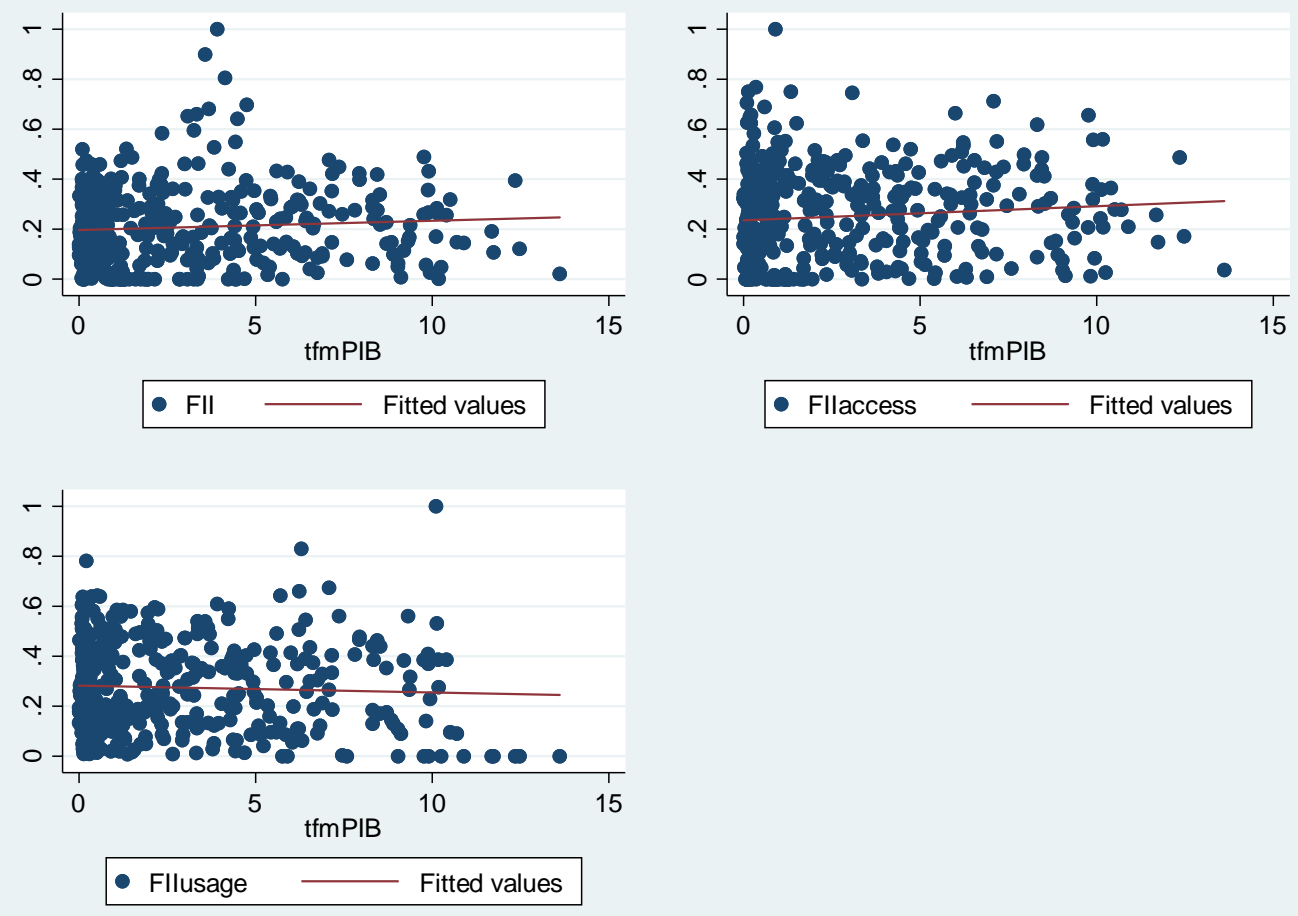

Source: Author's computation

The figure 1 show that a positive relationship can be expected between remittances and financial inclusion. Pour le cas de notre échantillon, la croissance de transfert de fonds des migrants accroit l'inclusion financière de façon globale et de l'indice d'accès aux services financiers mais a un effet décroissant sur l'utilisation des services financiers.

\section{Test of cross-section dependence and unit root test}

Table 3 shows the cross-section dependence test according to Pesaran (2004) and Pesaran (2015). Indeed the Pesaran (2004) test the strong existence of a cross-sectional dependence or the Pesaran (2015) test residuals or a variable for weak cross sectional dependence in a panel data. 
International Journal of Social Science and Economic Research

ISSN: 2455-8834

Volume: 05, Issue: 06 "June 2020"

Table 3: Cross-section dependence test of Pesaran (2004) and Pesaran (2015)

\begin{tabular}{|l|l|l|}
\hline Variables & Pesaran (2004) & Pesaran (2015) \\
\hline remit & $1.68^{*}$ & $61.782^{* * *}$ \\
\hline FII & $19.21^{* * *}$ & $54.996^{* * *}$ \\
\hline HDI & $73.55^{* * *}$ & $75.360^{* * *}$ \\
\hline goveexp & $4.20^{* * *}$ & $73.015^{* * *}$ \\
\hline inflation & $10.92^{* * *}$ & $54.840^{* * *}$ \\
\hline POPDENSITY & $75.29^{* * *}$ & $75.336^{* * *}$ \\
\hline POPGROWTH & $9.65^{* * *}$ & $74.626^{* * *}$ \\
\hline internet & $69.05^{* * *}$ & $71.347 * * *$ \\
\hline ICRGmean & $27.38^{* * *}$ & $75.162^{* * *}$ \\
\hline FIIusage & $26.44^{* * *}$ & $59.910^{* * *}$ \\
\hline FIIaccess & $20.94^{* * *}$ & $52.470^{* * *}$ \\
\hline Note $: * * * \mathrm{p}<0.01, * * \mathrm{p}<0.05$ & and ${ }^{* *} \mathrm{p}<0.1$ & \\
\hline
\end{tabular}

Source: Authors

This analysis shows that all the variables in our study have strong and weak cross-sectional dependence.

In the presence of cross-sectional dependence, the first-generation unit root test is biased, so it is essential to perform a second-generation unit root test. For this fact, we use the unit root tests of Pesaran (2003) and Pesaran (2007). It appears that our variables are stationary in level and difference. Table 4 shows the results on the different variables. 
International Journal of Social Science and Economic Research

ISSN: 2455-8834

Volume: 05, Issue: 06 "June 2020"

Table 4: Unit root test of Pesaran (2003, 2007)

\begin{tabular}{|c|c|c|c|c|c|}
\hline \multirow[t]{2}{*}{ Variables } & \multicolumn{2}{|c|}{ Pesaran (2003) } & \multicolumn{2}{|c|}{ Pesaran (2007) } & \multirow[t]{2}{*}{ Décision } \\
\hline & A niveau & $1^{\text {ère }}$ différence & A niveau & $1^{\text {ère }}$ différence & \\
\hline remit & 1.089 & -0.597 & $-2.401 * * *$ & $-3.664 * * *$ & $\mathrm{I}(0)$ \\
\hline FII & $-3.394 * * *$ & $-4.351 * * *$ & $-2.659 * * *$ & $-3.118 * * *$ & $\mathrm{I}(0)$ \\
\hline HDI & 0.440 & -0.680 & -1.765 & $-2.817 * * *$ & I (1) \\
\hline goveexp & $-3.614 * * *$ & $-5.428 * * *$ & -2.055 & $-3.335^{* * *}$ & $\mathrm{I}(0)$ \\
\hline inflation & $-2.731 * * *$ & $-2.881 * * *$ & $-2.667 * * *$ & $-3.988 * * *$ & $\mathrm{I}(0)$ \\
\hline POPDENSITY & $-8.789 * * *$ & $-5.745 * * *$ & -1.248 & -0.937 & $\mathrm{I}(0)$ \\
\hline POPGROWTH & $-4.802 * * *$ & $-4.156 * * *$ & -1.208 & -0.532 & $\mathrm{I}(0)$ \\
\hline internet & 2.810 & -0.749 & -1.116 & $-2.685^{* * *}$ & I (1) \\
\hline ICRGmean & $-4.389 * * *$ & $-3.952 * * *$ & $-2.347 * * *$ & $-3.343 * * *$ & $\mathrm{I}(0)$ \\
\hline FIIusage & $-2.558 * * *$ & $-6.615 * * *$ & $-2.178^{*}$ & $-3.837 * * *$ & $\mathrm{I}(0)$ \\
\hline FIIaccess & $-3.323 * * *$ & $-2.918 * * *$ & $-2.512 * * *$ & $-2.972 * * *$ & $\mathrm{I}(0)$ \\
\hline
\end{tabular}

Source: Author's

\subsection{Methodology}

This section specifies the methodology adapted to examine the link between migrant remittances and financial inclusion. In this paper we adopt a system GMM to examine the dynamic effect of remittances on financial inclusion. Then for robustness we consider the short- and long-term effect by adopting a Pooled Mean Group (PMG). The PMG allows us to see whether the results obtained with the GMM are short- or long-term results.

\subsubsection{System GMM}

We use a GMM in system as well as the work of Chuc et al (2019) to take into account the potential endogeneity problem. Our equation takes this form:

$F I I_{i t}=\beta_{0}+\beta_{1} F I I_{i, t-1}+\beta_{2}$ remit $_{i t}+X_{i t}+\varepsilon_{i t}$ 
International Journal of Social Science and Economic Research

ISSN: 2455-8834

Volume: 05, Issue: 06 "June 2020"

With $F I I_{i t}$ who represents the financial inclusion index of country $\mathrm{i}$ in year $\mathrm{t}$, remit ${ }_{i t}$ represents migrants' remittances, $X_{i t}$ represents the control variables and $\varepsilon_{i t}$ represents the error term.

\subsubsection{Pooled Mean Group (PMG)}

The GMM method just captures the short-term dynamics and ignores the long-term dynamics. To take into account the long-term dynamics, it is therefore appropriate to use a Pooled Mean Group (PMG) model developed by Pesaran et al (1999). Indeed, Pesaran et al (1999) suggests that for a large cross-section and a dynamic panel, panel regression and an error-correction model can be combined by applying an Auto Regressive Distributive Lag $\left(A R D L_{p, q}\right)$. The model can be written as follows:

$$
F I I_{i, t}=\varphi^{i}\left[F I I_{i, t-1}\left\{\beta_{0}^{i}+\beta_{1}^{i} X_{i, t-1}\right\}\right]+\sum_{j=1}^{p-1} \gamma_{j}^{i} F I I_{i, t-j}+\sum_{j=0}^{q-1} \delta_{j}^{i} \Delta X_{i, t-j}+\mu_{i}+\varepsilon_{i t}
$$

FII, the financial inclusion index $\delta$ and $\gamma$ represents respectively the short-term coefficient of the lagged independent and dependent variable, $\beta$ represents the long-term coefficient, $\mathrm{p}$ and $\mathrm{q}$ represents respectively the lagged dependent and independent variable, $\varphi$ is the coefficient of the speed of adjustment towards long-term equilibrium and $\varepsilon_{i t}$ the error term.

Specifically our equation (2) becomes equation (3) below:

$\Delta \mathrm{FII}_{\mathrm{i}, \mathrm{t}}=\alpha_{\mathrm{i}}+\sum_{\mathrm{j}=1}^{\mathrm{m}-1} \beta_{\mathrm{ij}} \Delta \mathrm{FII}_{\mathrm{i}, \mathrm{t}-\mathrm{j}}+\sum_{\mathrm{l}=0}^{\mathrm{n}-1} \varphi_{\mathrm{il}} \Delta \mathrm{remit}_{\mathrm{i}, \mathrm{t}-\mathrm{l}}+\sum_{\mathrm{r}=0}^{\mathrm{p}-1} \gamma_{\mathrm{ir}} \Delta \mathrm{POPGROWTH}_{\mathrm{i}, \mathrm{t}-\mathrm{r}}+$ $\sum_{\mathrm{u}=0}^{\mathrm{s}-1} \theta_{\mathrm{iu}} \Delta \mathrm{HDI}_{\mathrm{i}, \mathrm{t}-\mathrm{u}}+\sum_{\mathrm{w}=0}^{\mathrm{v}-1} \delta_{\mathrm{iw}} \Delta$ inflation $_{\mathrm{i}, \mathrm{t}-\mathrm{w}}+\sum_{\mathrm{z}=0}^{\mathrm{x}-1} \varphi_{\mathrm{iz}} \Delta$ internet $_{\mathrm{i}, \mathrm{t}-\mathrm{z}}+\sigma_{1}$ remit $_{\mathrm{i}, \mathrm{t}-1}+$ $\sigma_{2}$ HDI $_{\mathrm{i}, \mathrm{t}-1}+\sigma_{3}$ POPDENSITY $_{\mathrm{i}, \mathrm{t}-1}+\sigma_{4}$ POGROWTH $_{\mathrm{i}, \mathrm{t}-1}+\sigma_{5}$ goveexp $_{\mathrm{i}, \mathrm{t}-1}+\sigma_{6}$ inflation $_{\mathrm{i}, \mathrm{t}-1}+$ $\sigma_{7}$ internet $_{\mathrm{i}, \mathrm{t}-1}+\sigma_{8}$ ICRGmean $_{\mathrm{i}, \mathrm{t}-1} \varepsilon_{\mathrm{i}, \mathrm{t}}(3)$

To examine the effect of remittances on the use of financial services we adopt the following model:

$\Delta$ FIIusage $_{\mathrm{i}, \mathrm{t}}=\alpha_{\mathrm{i}}+\sum_{\mathrm{j}=1}^{\mathrm{m}-1} \beta_{\mathrm{ij}} \Delta$ FIIusage $_{\mathrm{i}, \mathrm{t}-\mathrm{j}}+\sum_{\mathrm{l}=0}^{\mathrm{n}-1} \varphi_{\mathrm{il}} \Delta$ remit $_{\mathrm{i}, \mathrm{t}-\mathrm{l}}+$

$\sum_{\mathrm{r}=0}^{\mathrm{p}-1} \gamma_{\mathrm{ir}} \Delta$ POPGROWTH $_{\mathrm{i}, \mathrm{t}-\mathrm{r}}+\sigma_{1}$ remit $_{\mathrm{it}-\mathrm{t}-1}+\sigma_{2} \mathrm{HDI}_{\mathrm{i}, \mathrm{t}-1}+\sigma_{3}$ POPDENSITY $_{\mathrm{i}, \mathrm{t}-1}+$

$\sigma_{4}$ POGROWTH $_{\mathrm{i}, \mathrm{t}-1}+\sigma_{5}$ goveexp $_{\mathrm{i}, \mathrm{t}-1}+\sigma_{6}$ inflation $_{\mathrm{i}, \mathrm{t}-1}+\sigma_{7}$ internet $_{\mathrm{i}, \mathrm{t}-1}+$ $\sigma_{8}$ ICRGmean $_{\mathrm{i}, \mathrm{t}-1} \varepsilon_{\mathrm{i}, \mathrm{t}}(4)$

To examine the impact of remittances on access to financial services we adopt equation (5) below: 
$\Delta$ FIIaccess $_{\mathrm{i}, \mathrm{t}}=\alpha_{\mathrm{i}}+\sum_{\mathrm{j}=1}^{\mathrm{m}-1} \beta_{\mathrm{ij}} \Delta$ FIIaccess $_{\mathrm{i}, \mathrm{t}-\mathrm{j}}+\sum_{\mathrm{l}=0}^{\mathrm{n}-1} \varphi_{\mathrm{il}} \Delta_{\text {remit }_{\mathrm{i}, \mathrm{t}-\mathrm{l}}}+$

$\sum_{\mathrm{r}=0}^{\mathrm{p}-1} \gamma_{\mathrm{ir}} \Delta$ POPGROWTH $_{\mathrm{i}, \mathrm{t}-\mathrm{r}}+\sigma_{1}$ remit $_{\mathrm{it}-\mathrm{t}-1}+\sigma_{2}$ HDI $_{\mathrm{i}, \mathrm{t}-1}+\sigma_{3}$ POPDENSITY $_{\mathrm{i}, \mathrm{t}-1}+$ $\sigma_{4}$ POGROWTH $_{\mathrm{i}, \mathrm{t}-1}+\sigma_{5}$ goveexp $_{\mathrm{i}, \mathrm{t}-1}+\sigma_{6}$ inflation $_{\mathrm{i}, \mathrm{t}-1}+\sigma_{7}$ internet $_{\mathrm{i}, \mathrm{t}-1}+$ $\sigma_{8}$ ICRGmean $_{\mathrm{i}, \mathrm{t}-1} \varepsilon_{\mathrm{i}, \mathrm{t}}(5)$

\section{EMPIRICAL FINDINGS}

\section{Remittances and financial inclusion nexus: system GMM estimation result}

There is no evidence of a second serial correlation, but a strong evidence of a first correlation. Then, regression successfully pass Sargan specification test as well as error term serial correlation tests (AR1 and AR2) and confirm the validity of instruments.

Table 5: GMM estimate of the relationship between remittances and financial inclusion

\begin{tabular}{|c|c|c|c|}
\hline & \multicolumn{3}{|c|}{ GMM } \\
\hline & FII & FIIusage & FIIaccess \\
\hline \multirow[t]{2}{*}{ L.FII } & $0.669 * * *$ & & \\
\hline & $(0.172)$ & & \\
\hline \multirow[t]{2}{*}{ L.FIIusage } & & $0.755 * * *$ & \\
\hline & & $(0.140)$ & \\
\hline \multirow[t]{2}{*}{ L.FIIaccess } & & & $0.762 * * *$ \\
\hline & & & $(0.144)$ \\
\hline \multirow[t]{2}{*}{ remit } & $-0.0795 * *$ & $0.0882^{*}$ & 0.0158 \\
\hline & $(0.0310)$ & $(0.0475)$ & $(0.0378)$ \\
\hline \multirow[t]{2}{*}{ HDI } & 0.0434 & 0.285 & 0.320 \\
\hline & $(0.176)$ & $(0.200)$ & $(0.225)$ \\
\hline \multirow[t]{2}{*}{ inflation } & $-0.00830 * * *$ & $-0.00631 * *$ & -0.00335 \\
\hline & $(0.00274)$ & $(0.00284)$ & $(0.00270)$ \\
\hline \multirow[t]{2}{*}{ POPDENSITY } & $0.00216^{* * *}$ & $-0.00164 *$ & -0.000151 \\
\hline & $(0.000733)$ & (0.000999) & $(0.000796)$ \\
\hline \multirow[t]{2}{*}{ POPGROWTH } & -0.0425 & $0.112 * *$ & 0.0337 \\
\hline & $(0.0423)$ & $(0.0517)$ & $(0.0430)$ \\
\hline \multirow[t]{2}{*}{ ICRGmean } & 0.0139 & 0.0174 & -0.0248 \\
\hline & $(0.0347)$ & $(0.0473)$ & $(0.0425)$ \\
\hline \multirow[t]{2}{*}{ Constant } & 0.247 & -0.567 & -0.110 \\
\hline & $(0.347)$ & $(0.397)$ & $(0.354)$ \\
\hline AR1 (p value) & 0.000 & 0.000 & 0.000 \\
\hline AR2 (p value) & 0.461 & 0.217 & 0.766 \\
\hline Sargan (p value) & 0.563 & 0.496 & 0.131 \\
\hline
\end{tabular}




\section{International Journal of Social Science and Economic Research}

ISSN: $2455-8834$

Volume: 05, Issue: 06 "June 2020"

\begin{tabular}{llll} 
Number of country & 29 & 29 & 29 \\
Observations & 375 & 375 & 375 \\
\hline Standards errors in parentheses $* * * \mathrm{p}<0.01, * * \mathrm{p}<0.05, * * * \mathrm{p}<0.1$ \\
Source: Author's
\end{tabular}

The results of the GMM system show us that remittances from migrants have a negative impact on financial inclusion in Africa. Indeed, remittances to Africa according to Ratha et al (2010) in sub-Saharan African countries is more than $50 \%$ and remittances via the informal channel occupy 50 to $250 \%$ of the official statistics of migrant remittances according to Freund and Spatafora (2008). Thus, the more remittances pass through the informal sector, the more recipient households do not find it necessary to use financial intermediaries to deposit their surplus income. However, it should also be taken into account that the cost of sending international remittances is high and thus discourages migrants from using formal channels. Indeed, according to World Bank and Knomad (2019), the average overall cost of remittances is about 7\% in the first quarter of 2019. Moreover, remittances to Sub-Saharan Africa are 9.3\%, representing 3 times the target of the Sustainable Development Goals (SDGs).

According to the work of Lukman and Adeyemi (2019), remittances do not have a significant impact on financial inclusion in SSA. Furthermore, Kwesi et al (2020) shows that remittances from formal migrants in Kenya have a positive impact on financial inclusion due to the policies implemented by the government. Removing barriers and reducing the cost of remittances can improve access to and use of financial services (Ajefu and Ogebe, 2019). Therefore, with the high cost of remittances and a large share of this flow passing through the informal channel, this reduces its impact on financial inclusion.

Furthermore, our results show that remittances from migrants have a positive impact on the use of financial services but have no impact on access to services although the latter is positive. Our results are contrary to the findings of Chuc et al (2019) which shows that remittances are a substitute for credit. In this work, it appears that remittances can play a complementary role to the use of financial services by reducing the liquidity constraint. But this effect on the use of financial services is positively small.

\section{Pooled Mean Group estimation result}

However, it should be noted that these results refer to short-term effects using a GMM in system. In order to see the long term and short-term impact we use a Pooled Mean Group (PMG) model. In addition, we add in the control variables the effect of internet access on financial inclusion (Olaniyi, 2018) and government investment as is the case in the work of Chuc et al (2019). 
International Journal of Social Science and Economic Research

ISSN: 2455-8834

Volume: 05, Issue: 06 "June 2020"

Table 6: Remittances and financial inclusion: Pooled Mean Group estimation

\begin{tabular}{|c|c|c|c|c|c|}
\hline & Variables & FII & FII & FIIaccess & FIIusage \\
\hline \multirow[t]{5}{*}{$\begin{array}{l}\text { Long } \\
\text { run }\end{array}$} & remit & $\begin{array}{l}.0656782 * * * \\
(.0021599)\end{array}$ & $\begin{array}{l}.0522351 * * * \\
(.0027108)\end{array}$ & $\begin{array}{l}.0262164 * * * \\
(.0080475)\end{array}$ & $\begin{array}{l}-.0262044 * * * \\
(.0030172)\end{array}$ \\
\hline & inflation & $\begin{array}{l}-.002897 * * * \\
(.000318)\end{array}$ & $\begin{array}{l}-.0026334 * * * \\
(.0002919)\end{array}$ & & \\
\hline & HDI & $\begin{array}{l}.1132031 * * * \\
(.013756)\end{array}$ & & & \\
\hline & internet & & $\begin{array}{l}.0020735^{* * * *} \\
(.000211)\end{array}$ & & \\
\hline & POPGROWTH & & & $\begin{array}{l}-1.082425 * * * \\
(.0276823)\end{array}$ & $\begin{array}{l}-.177262 * * * \\
(.0290421)\end{array}$ \\
\hline \multirow[t]{8}{*}{$\begin{array}{l}\text { Short } \\
\text { run }\end{array}$} & ECT & $\begin{array}{l}-.6637885 * * * \\
(.1511034)\end{array}$ & $\begin{array}{l}-.6716655 * * * \\
(.1515667)\end{array}$ & $\begin{array}{l}.5323233 * * * \\
(.1704227)\end{array}$ & $\begin{array}{l}-.8372684 * * * \\
(.1423727)\end{array}$ \\
\hline & remit & $\begin{array}{l}-.2204385^{*} \\
(.1265524)\end{array}$ & $\begin{array}{l}-.1265116^{*} \\
(.0689137)\end{array}$ & $\begin{array}{l}.1025458 \\
(.0805059)\end{array}$ & $\begin{array}{l}.0877918 \\
(.2004535)\end{array}$ \\
\hline & HDI & $\begin{array}{l}-1.267322 \\
(4.776106)\end{array}$ & $\begin{array}{l}-.9909363 \\
(4.64577)\end{array}$ & $\begin{array}{l}12.3204 \\
(8.3409)\end{array}$ & $\begin{array}{l}-6.391084 \\
(6.635059)\end{array}$ \\
\hline & POPDENSITY & $\begin{array}{l}.2413485 \\
(.3089223)\end{array}$ & $\begin{array}{l}.2182577 \\
(.3080472)\end{array}$ & $\begin{array}{l}1.308874 \\
(1.594743)\end{array}$ & $\begin{array}{l}1.000009 \\
(1.310518)\end{array}$ \\
\hline & POPGROWTH & $\begin{array}{l}-.0767951 \\
(1.273814)\end{array}$ & $\begin{array}{l}-.0122939 \\
(1.281167)\end{array}$ & $\begin{array}{l}-2.75797 \\
(3.297486)\end{array}$ & $\begin{array}{l}.9049065 \\
(1.705061)\end{array}$ \\
\hline & goveexp & $\begin{array}{l}-.012881 \\
(.0131241)\end{array}$ & $\begin{array}{l}-.0128341 \\
(.013365)\end{array}$ & $\begin{array}{l}-.0241944 \\
(.0207876)\end{array}$ & $\begin{array}{l}.0213577 \\
(.0191577)\end{array}$ \\
\hline & inflation & $\begin{array}{l}.0055576 \\
(.0036285)\end{array}$ & $\begin{array}{l}.0053944 \\
(.0037587)\end{array}$ & $\begin{array}{l}.0079969 \\
(.0073231)\end{array}$ & $\begin{array}{l}.0079969 \\
(.0051013)\end{array}$ \\
\hline & internet & -.0043198 & -.0051738 & -.0432451 & .0066893 \\
\hline
\end{tabular}


International Journal of Social Science and Economic Research

ISSN: $2455-8834$

Volume: 05, Issue: 06 "June 2020"

\begin{tabular}{|l|l|l|l|l|l|}
\hline & $(.0105461)$ & $(.0105585)$ & $(.0338187)$ & $(.0155689)$ \\
\cline { 3 - 6 } & ICRGmean & .119903 & .1165681 & -.2138048 & .1505801 \\
& $(.0927137)$ & $(.0919859)$ & $(.1378558)$ & $(.1324114)$ \\
\cline { 3 - 6 } & cons & .2190276 & .2673282 & 1.387273 & .6663214 \\
& $(.2806209)$ & $(.285533)$ & $(1.052887)$ & $(.4367653)$ \\
\hline
\end{tabular}

Standards errors in parentheses $* * * p<0.01, * * p<0.05, * * * p<0.1$

Source: Authors

The results of the PMG model show us that the results found using the GMM in-system model are short-term effects with the exception of the access to financial services dimension.

The PMG results show us that migrant remittances have a negative short-term impact on financial inclusion but a positive long-term impact. Moreover, by adding the variable internet access we find that internet access increases financial inclusion (Olaniyi, 2018). Moreover, remittances may have a negative effect on financial service use in the long run because this flow would act as a substitute for the demand for credit. Indeed, even as the receipt of remittances leads to the demand for a deposit account (Demirguc-Kunt et al., 2011), it is also a substitute for credit in countries with greater credit constraints (Giuliano and Ruiz-Arranz 2009) and hence a lower demand for credit. Moreover, according to Ambrosius and Cuecuecha (2016), the effect of remittances on credit is driven by informal finance to the detriment of traditional lending through formal financial intermediaries. Thus, the increase in migrant remittances is unlikely to encourage the use of formal financial services (Chuc et al., 2019).

\section{Dumitrescu and Hurlin causality test (2012)}

This study also uses the panel causality test of Dumitrescu and Hurlin (2012) to examine the potential link between migrant remittances and financial inclusion in Africa. Indeed, the study of causality allows for more appropriate economic policy recommendations. Dumitrescu and Hurlin's (2012) test is based on the null hypothesis of no causality for the panel versus the alternative hypothesis of causality for at least one unit in the panel. It is based on a linear dynamic panel test in which the following equation is used:

$y_{i t}=\alpha_{i}+\sum_{k=1}^{k} \beta_{i k} y_{i(t-k)}+\sum_{k=1}^{k} \gamma_{i k} x_{i(t-k)}+\varepsilon_{i t}$

Where $\mathrm{k}$ is the number of delays and $\varepsilon_{i t}$ the error term. The above equation allows us to examine the causal effect of variable X on variable Y. Dumitrescu and Hurlin (2012) proposed a mean statistic of Wald's test to test the null hypothesis. Wald's statistic is given as follows: 
$\bar{W}_{N T}=\frac{1}{N} \sum_{i=1}^{N} W_{i T}$

Where's $W_{i T}$ the Wald individual statistic for Granger's causality test. The Wald test statistic is independently and identically distributed and the panel causality test is:

$\bar{Z}=\sqrt{\frac{N}{2 K}}\left(\bar{W}_{N T}-K\right)$

Furthermore, the causality test of Dumitrescu and Hurlin (2012) has the advantage of taking into account the potential problem of cross-section dependency by implementing a bootstrap procedure to calculate the critical values of the test. Before implementing this causality test, the cross-section dependency test is conducted for each variable (see Table 3) using the CD test of Pesaran (2004 and 2015).

Table 7: Dumitrescu et Hurlin (2012) Granger non-causality test results

\begin{tabular}{|l|l|l|}
\hline Hypothèse nulle & \multicolumn{1}{|c|}{ z-bar } & \multicolumn{1}{|c|}{ lag } \\
\hline FII does not Granger-cause remit. & 1.5463 & 1 \\
\hline remit does not Granger-cause FII & $4.3616^{* * *}$ & 1 \\
\hline FIIusage does not Granger-cause remit. & $3.6639^{* * *}$ & 1 \\
\hline remit does not Granger-cause FIIusage. & -0.0431 & 1 \\
\hline FIIaccess does not Granger-cause remit & 1.5939 & 1 \\
\hline remit does not Granger-cause FIIaccess. & $8.3551^{* * *}$ & 1 \\
\hline H0: internet does not Granger-cause FII & $17.0063^{* * *}$ & 1 \\
\hline H0: FII does not Granger-cause internet & $3.0010^{* * *}$ & 1 \\
\hline
\end{tabular}

Source: Authors

Dumitrescu and Hurlin's (2012) causality test shows us that there is a unidirectional causality between remittances and financial inclusion. Moreover, the use of financial services impacts the receipt of remittances. There is unidirectional causality between remittances and access to financial services. In addition, there is a two-way relationship between financial inclusion and internet access. 
International Journal of Social Science and Economic Research

ISSN: 2455-8834

Volume: 05, Issue: 06 "June 2020"

\section{CONCLUSION}

In this paper we examine the dynamic effect and the short- and long-term effect of migrant remittances on financial inclusion in a sample of 29 African countries from 2004 to 2017. Based on a GMM system model that solves the potential endogeneity problem and the PMG model that allows us to observe the short- and long-term dynamics, we find that remittances have a negative short-term impact on financial inclusion but a positive long-term impact. Furthermore, by considering our two dimensions of financial inclusion (access and use of financial services) separately, we find that in the long run, remittances have a negative impact on the use of financial services but a positive impact on access to financial services. Thus, remittances play a role as a substitute for the use of financial services.

To benefit from remittances, governments will need to implement a policy of attracting remittances to formal channels by removing barriers and reducing the costs of sending remittances.

\section{REFERENCES}

Aggarwal, R., A. Demirguc-Kunt, M. Soledad, and M. Peria (2011) "Do Emittances Promote Financial Development?" Journal of Development Economics 96: 255-264.

Ajefu, J. B., and J. Ogebe (2019) "Migrant Remittances and Financial Inclusion among Households in Nigeria" Oxford Development Studies 47(3): 319-335.

Ambrosius, C., and A. Cuecuecha (2016) "Remittances and the Use of Formal and Informal Financial Services" World Development 77: 80-98.

Ambrosius, C., B. Fritz, and U. Stiegler (2014) "Remittances for Financial Access: Lessons from Latin American Microfinance". Development Policy Review 32(6): 733-753.

Ambrosius,C. (2016) "Remittances and financial access: Is there really a link and for whom? Evidence from Mexican household data" The World Economy, 39 (7), pp: 964-982.

Andrianaivo M. et Kpodar K. (2012) "Mobile phone use spurs economic growth through financial inclusion" Review of Economics and Institutions, 3(2).

Anzoategui, D., A. Demirguc-Kunt, and M. S. M. Peria (2014) "Remittances and Financial Inclusion: Evidence from El Salvador" World Development 54: 338-349.

Arindam Laha (2015) "Association between financial inclusion and human development in south asia: A cross-country analysis with special reference to india" Journal of Economic Policy and Research, Vol 10, No.2 


\section{International Journal of Social Science and Economic Research}

ISSN: $2455-8834$

Volume: 05, Issue: 06 "June 2020"

Beck, T., Demirguc-Kunt, A. and Peria, M.S.M. (2007) "Reaching out: Access to and use of banking services across countries" Journal of Financial Economics 85(1): 234-266.

Brown, R. P. C., F. Carmignani, and G. Fayad. (2013) "Migrants' Remittances and Financial Development: Macro- and Micro-level Evidence of a Perverse Relationship" The World Economy 36(5): 636-660.

Chuc Anh Tu, Nguyet Thi Minh Phi, Le Quoc Tuan, Naoyuki Yoshino, Tapan Sarker, and Farhad Taghizadeh-Hesary (2019) "Remittance inflows, financial inclusion, and economic development: an empirical analysis of the world sample" ADBI Working Paper Series, No. 1000

Demirguc-Kunt, A., E. Lopez Cordova, M. S. Martınez Perı, and C. Woodruff (2011) "Remittances and Banking Sector Breadth and Depth: Evidence from Mexico" Journal of Development Economics 95(2): 229-241.

Dumitrescu, E-I., Hurlin, C. (2012) "Testing for Granger non-causality in heterogeneous panels" Economic Modelling. 29(4), 1450-1460.

Durga P. Gautam (2019) Do remittances promote financial inclusion?, J. C. Hall, S. Harper (eds.), Economic and Political Institutions and Development, https://doi.org/10.1007/978$\underline{3-030-06049-76}$

Freund, C., \& Spatafora, N. (2008) "Remittances, transaction costs, and informality" Journal of Development Economics, 86(2), 356-366. doi: 10.1016/j.jdeveco.2007.09.002

Gemechu Ayana Aga and Maria Soledad Martinez Peria (2014) "International remittances and financial inclusion in Africa", World Bank

Giuliano, P., and M. Ruiz-Arranz. (2009) "Remittances, Financial Development, and Growth" Journal of Development Economics 90: 144-152.

Global Findex (2017), Measuring financial inclusion and Fintex revolution, Washington DC

Global Migration Group (2017), Migration, remittances and financial inclusion: challenges and opportunities for women's Economic Empowerment, GMG Report

Gupta, S., C. Pattillo, and S. Wagh. (2009). Effect of Remittances on Poverty and Financial Development in Sub-Saharan Africa. World Development 37(1): 104-115.

Inoue, T., and S. Hamori. (2016) "Do Workers' Remittances Promote Access to Finance? Evidence from Asia-Pacific Developing Countries”. Emerging Markets Finance and Trade 52(3): 765-774. 
International Journal of Social Science and Economic Research

ISSN: $2455-8834$

Volume: 05, Issue: 06 "June 2020"

Kempson E, A. Atkinson et O. Pilley (2004) "Policy level response to financial exclusion in developed economies: lessons for developing countries" Report of Personal Finance Research Centre, University of Bristol.

Kpodar, K., and M. Andrianaivo. (2011) "ICT, Financial Inclusion, and Growth Evidence from African Countries” IMF Working Paper/11/73.

Kwesi Emmanuel Arthur, Salome Mwongeli Musau and Festus Mithi Wanjohi (2020) "Diaspora Remittances and Financial Inclusion in Kenya" European Journal of Business and $\begin{array}{lllll}\text { Management Research, Vol. } & \text { No. } & \text { DOI: }\end{array}$ http://dx.doi.org/10.24018/ejbmr.2020.5.2.289

Lenk S. K. et Barik, R. (2018) "Has expansion of mobile phone and internet use spurred financial inclusion in the SAARC countries?" Financial Innovation, 4(5). doi: https://doi.org/10.1186/s40854-018-0089-x

Lucas R. E. B, and O. Stark (1985), "Motivations to Remit: Evidence from Botswana" Journal of Political Economy, vol. 93, no. 5, pp. 901-918, 1985.

Lukman.O. Oyelami \& Adeyemi A. Ogundipe | (2020) An empirical investigation of remittances and financial inclusion nexus in Sub-Saharan Africa, Cogent Business \& Management, https://doi.org/10.1080/23311975.2020.1712126

Mialou André, Goran Amidzic et Alexander Massara (2017) “Assessing Countries’ Financial Inclusion Standing - A New Composite Index", Journal of Banking and Financial Economics 2(8), pp: 105-126, 10.7172/23536845.jbfe.2017.2.5

Stark O. (1991) "The Economics of International Labour Migration," Population Studies, vol. 44, no. 1, pp. 181-182.

Olaniyi Evans (2018) "connecting the poor: the internet, mobile phones and financial inclusion in Africa" Digital Policy Regulation and Governance

Orozco, M., and R. Fedewa (2006) "Leveraging Efforts on Remittances and Financial Intermediation". INTAL-ITD: Inter-American Development Bank.

Pesaran M. H (2003) "Estimation and inference in large heterogenous panels with cross section dependence", CESifo Working Paper Series

Pesaran M. H (2015) "Testing weak cross-sectional dependence in large panels" Econometric Reviews 34 (6-10), 1089-1117 
International Journal of Social Science and Economic Research

ISSN: 2455-8834

Volume: 05, Issue: 06 "June 2020"

Pesaran M. H, Yongcheol Shin, Ron P Smith (1999) "Pooled mean group estimation of dynamic heterogeneous panels", Journal of the American statistical association 94(446), 621-634

Pesaran, M.H. (2004) "General diagnostic tests for cross section dependence in panels" CESifo working paper series No 1219

Pesaran, M.H. (2007) "A simple panel unit root test in the presence of cross-sectional dependence" Journal of Applied Econometrics. 22(2), 265-312.

Pesaran, M.H., Shin, Y., Smith, R.P. (1999) "Pooled mean group estimation of dynamic heterogeneous panels". Journal of the American Statistical Association. 94(446), 621634.

R. Misati, and A. Kamau (2018), "Do Migrant Remittances Matter for Financial Development in Kenya?" The Kenya Bankers Association (KBA) Working Papers, no. 30, WPS/08/18.

Ratha D., S. Mohapatra and A. Silwal (2010) Migration and remittances factbook 2011, Washington DC: World Bank Group

Roa, M. J. (2015) "Financial Inclusion in Latin America and the Caribbean: Access, Usage and Quality" Research Papers 19. CEMLA.

Sarma Mandira, (2015) "Measuring financial inclusion" Economics Bulletin, Volume 35, Issue 1, pp: 604-611

Sarma, M. (2008) “Index of Financial Inclusion” ICRIER Working Paper 215.

Sarma, M., and J. Pais (2011) "Financial Inclusion and Development" Journal of International Development 23(5): 613-628.

Wang, X. and Guan, J. (2017) "Financial Inclusion: Measurement, spatial effects, and influencing factors" Applied Economics 49(18): 1751-1762.

World Bank (2014). Global Economic Prospectus. Washington, DC.

World Bank (2005). Global Economic Prospects Report 2006: Economic Implications of Remittances and Migration. Washington, DC: World Bank.

World Bank and Knomad (2019) Migration and remittances: recent developments and outlook, Migration and Development Brief 31 April 2019,

Yoshino, N., F. Taghizadeh-Hesary, and M. Otsuka (2017) "International Remittances and Poverty Reduction: Evidence from Asian Developing Countries" ADBI Working Paper 759. Tokyo: Asian Development Bank Institute. 
Yoshino, N., P. J. Morgan, and L. Q. Trinh. (2017) "Financial Literacy in Japan: Determinants and Impacts” ADBI Working Paper 796.

\section{Appendix}

List of countries in sample

Angola Botswana Burkina Faso Cote d'Ivoire Malawi Mali Niger Democratic Republic of Cong Senegal Sierra Leone South Africa Algeria Cameroon Congo Egypt Gabon Ghana Kenya Madagascar Morocco Namibia Nigeria Sudan Tanzania Togo Tunisia Uganda Zambia and Zimbabwe. 